\title{
Camilian lexical substitutions
}

\author{
Carlota Pimenta
}

Centre of Linguistics, University of Lisbon, Portugal

https://doi.org/10.36505/ExLing-2019/10/0042/000404

\begin{abstract}
With the theoretical and methodological framework of genetic criticism, this research focuses on the lexical substitutions made by Camilo Castelo Branco, one of the most relevant Portuguese Romantic writers, in the autographs of Novelas do Minho and Amor de Perdição, two major works of his. Through their analysis, an attempt is made to clarify his lexical ascertainment, specifically regarding lexical complexification, in two different periods of Camilian literary production.
\end{abstract}

Key words: genetic criticism, Camilo Castelo Branco, lexical substitutions

\section{Introduction}

In my PhD thesis (Pimenta 2017), I transcribed, collected and sorted in a database the corrections found in the manuscript of Novelas do Minho, classified according to an analytical typology that revised and expanded the model previously proposed by Castro (2007). The present study now proposes to explore one of the types of genetic phenomenon registered at that time, the lexical substitutions, trying to demonstrate the usefulness of their analysis to deepen the knowledge about the way Camilo handled language.

This study explores the hypothesis proposed by Feijó (2011), according to which the continuous polishing of language by Camilo, often translated into a wider linguistic choice, is one example of continuity in Camilian writing. For this study, a sample of four novellas edited in successive years was selected Gracejos que matam (GM) and Cego de Landim (CL) (1875), Maria Moisés (MM) (1876) and A Viúva do Enforcado ( $V E)$ (1877) - and the substitutions of the novel Amor de Perdição (AP) (1861) were also analysed (based on Castro 2007), in order to enable the comparison of this aspect in works of different periods.

\section{Method}

The method was based on examining the substitutions that include less common terms. This method involves a margin of error that arises from the fact that nowadays we do not know the frequency of use that each word had at the time Camilo wrote. In an attempt to ascertain the degree of strangeness of the selected words, an exhaustive check of these terms was made in António de Morais Silva's Dictionary of the Portuguese Language, which constitutes "the most important reference in the history of Portuguese lexicography" (Verdelho

ExLing 2019: Proceedings of $10^{\text {th }}$ International Conference of Experimental Linguistics, 25-27 September 2019, Lisbon, Portugal 
2003). Camilo Castelo Branco used it frequently and advised his readers to consult it.

\section{Results}

This study concluded that of 150 substitutions selected in Amor de Perdição and of 500 substitutions selected in Novelas do Minho, 20 less common words from the novel and 60 less common words from the novellas are not to be found in the second edition (1813) of Morais Silva's dictionary. This, for example, is the case with the noun "objurgatória" (censure) (AP: 20) and the adjective "esparavonada" (GM: 26), derived from the noun "esparavão", a veterinary term which designates a tumor below the curve of a horse's leg.

The less common words that are missing in the $2^{\text {nd }}$ edition were added in later editions. In fact, Morais Silva's dictionary, which appeared in 1789, was successively reprinted throughout the nineteenth century, with additions involving nomenclature and quotations from modern writers. Some words did not yet exist in the $6^{\text {th }}$ edition (1858), the latest edition available on the dates Camilo wrote the novel and the novellas. This is, for example, the case with the term "amantar" (cover with a blanket), which was only added in the $7^{\text {th }}$ edition (1878). This word appears in the sentence "deixe-me ir $<$ desaparelhar $>$ amantar a egua" ("let me <unsaddle> put a blanket on the mare") ${ }^{1}(A P: 132)$, that is the example presented in the $10^{\text {th }}$ edition (1949).

Indeed, the $10^{\text {th }}$ edition often presents examples taken from Camilo's own works and some of these examples are precisely the final versions resulting from lexical substitutions found in Amor de Perdição and Novelas do Minho. This is also the case with the noun "aferro" (vehement desire), included in the $2^{\text {nd }}$ edition, which appears in the $10^{\text {th }}$ edition with the example " $<$ o amor $>0$ $<$ desejo de viver $>$ aferro á vida que lhe foge" (" $<$ the love $>$ the $<$ desire to live $>$ vehement desire for life that runs from him") (AM: 274) and is also the case with the verb "exorcismar" where the $2^{\text {nd }}$ edition explicitly states "exorcizar (exorcising) is what one should say". In the $10^{\text {th }}$ edition, this term is referenced with the sentence "- Vai-te, vai-te, jacobino; cruzes, deabo, cruzes! - <exclamou> exorcismon a tia" ("- Go, go, Jacobin; crosses, devil, crosses! - <exclaimed> exorcised the aunt") (MM: 4). Finally, this also happens with the adjective "seva" (ignoble), added in the $5^{\text {th }}$ edition (1844) and attested in the $10^{\text {th }}$ edition with the example "Era uma <pungente $>[\uparrow$ seva $]$ calumnia" ("It was a $<$ painful $>$ [个ignoble] calumny") (GM: 34$)$.

Even more interesting is the case of words that were only added in the $10^{\text {th }}$ edition using examples from Camilo resulting from his revision work. This is the case of the verb "paxalizar", derived from "paxa" (pascha; idler, in the figurative sense), in the phrase "consignadas aos Cressos da rua do Ouvidor, $<\mathrm{e}$ aos nossos irmãos $>$ [ $\uparrow$ que pachalisavam nas chacaras da Tejuca" ("consigned to the wealthy from Ouvidor's street, <and to our brothers> that idled in the ranches of Tejuca) (CL: 6) and the adverb "enxundiosamente" derived from 
"enxúndia" (fat), which occurs in "<engordando a po $>$ [个arredondando-se] tão enxundiosamente que parecia todo ele a barriga do gigante Typheu" (" $<$ fatting $>$ [ $\uparrow$ rounding out himself] so full of fat that all of him looked like the belly of the giant Tython") (VE 1: 11). Both cases result from innovations in the language.

Words that were classified in the $2^{\text {nd }}$ edition as ancient or little used forms were also found in Camilian substitutions. An example of a little used word is the noun "latibulo" (hiding place) (CL: 16). Examples of ancient forms are the adjective "afreimado" (irate), in the substitution "- Vamos, q é tarde, vamos! disse $\mathrm{mt}^{\mathrm{o}}<$ açodada>[个afreimada]" ("- Come on, it's late, let's go! - she said $<$ rushed $>[\uparrow$ irate $]$ ") (VE 1:20) and the verb "prantar", an ancient and popular form of "plantar" (put), which appears in the phrase "Vais-te < por $>[\uparrow$ prantar $]$ a pé, rapariga? (“Are you going to stand up, girl?”) (MM: 33). These two examples resulting from substitutions were presented in the $10^{\text {th }}$ edition.

In the process of replacing a more common term with a less common one, one can sometimes see hesitations in writing that seem to provide evidence of doubt when establishing the less common term. Thus, for example, in the phrase " $<$ bebeu $>[\uparrow<$ g $<$ ar $>/$ ol $\backslash$ guelejou $>$ gargalacou $]$ da borracha uma vez de vinho" ("< $<$ drank $>[\uparrow<$ gargled $>$ gargalacou $]$ from the wineskin a large amount of wine") (MM: 3), the verb "beber" (drink) was first replaced by the form "garguerejou", which was amended to "golguerejou". These two forms resemble the verbs "gargarejou" (to conserve a liquid in the throat without swallowing it) and "gorgolejou" (when drinking, to produce the noise of gargling). This hesitancy in writing seems to suggest Camilo's doubts as to the form to be established, having finally opted for a similar but less common verb "gargalaçou" (to drink, by inserting the neck of the vessel into the mouth). This verb was only added in the $7^{\text {th }}$ edition of Morais Silva's dictionary.

Although the process of replacing a more common term with a less common one is dominant in the corpus studied, the opposite also happens. Sometimes, a less common term is rejected and replaced by a more common one. Examples of rejected terms are the verb "presar" (VE 2: 28), which the $2^{\text {nd }}$ edition considers as an ancient form of "apresar" (capture), and the verb "jornandeando" (travelling) (AP: 200), which is added in the $8^{\text {th }}$ edition (1889) as a modern term. Reference is also made to the word "ovarina" (natural or inhabitant of Ovar) (AP: 24), added in the $9^{\text {th }}$ edition (no date), and to the forms "repungia-se" (deeply tormented) (AP: 278) and "despedaçadora" (thing that shatters) (VE 1: 24), that only appear in the $10^{\text {th }}$ edition.

\section{Conclusion and future perspectives}

Although the work of lexical ascertainment is more intense in the manuscript of Novelas do Minho than in the manuscript of Amor de Perdição (cf. Pimenta 2017), this study suggests that the search for lexical complexification is present in both works, which, having been produced in different periods of the life of the 
writer, seem to indicate that this may be a constant throughout the creative process of Camilo.

Future developments could be made based on a computer application designed to verify the frequency of each word or phrase replaced in corpora including Portuguese texts of the second half of the nineteenth century. A platform that would provide free access not only to the forms within the Camilian linguistic heritage which are already known (originating from the published versions of his works) but also the linguistic forms that were rejected, as well as the genetic relation between them, would make a significant contribution to the study of the Camilian lexicon and its practical applications in literary and cultural analysis and would also provide a meaningful contribution to studies of Language History and Lexicography.

\section{Notes}

Genetic symbols: < > deletion; [ $\uparrow$ ] substitution above the line; / \overlapping substitution.

\section{References}

Castro, I. 2007. Camilo Castelo Branco, Amor de Perdição. Critical and genetic edition. Lisbon, IN-CM.

Feijó, E. 2011. O Legado do Último Camilo Romancista e a (Auto)Cilada realista. Vila Nova de Famalicão, Casa de Camilo.

Pimenta, C. 2017. O processo de escrita camiliano em Novelas do Minho. Análise genética. PhD thesis in Textual Criticism. School of Arts and Humanities of the University of Lisbon.

Verdelho, T. 2003. O dicionário de Morais Silva e o início da lexicografia moderna. In História da língua e história da gramática - actas do encontro, 473-490, Braga, Universidade do Minho. 